Ivan Ristić ${ }^{*}$, Aleksandra Miletić ${ }^{1}$, Ivan Krakovsky², Suzana Cakić ${ }^{3}$, Branka Pilić ${ }^{1}$, Miroslav Cvetinov ${ }^{4}$

${ }^{1}$ University of Novi Sad, Faculty of Technology, Novi Sad, Serbia, ${ }^{2}$ Charles University, Faculty of Mathematics and Physics, Praha, Czech Republic, ${ }^{3}$ University of Niš, Faculty of Technology Leskovac, Leskovac, Serbia, ${ }^{4}$ University of Novi Sad, Faculty of Sciences, Novi Sad, Serbia

Scientific paper ISSN 0351-9465, E-ISSN 2466-2585 UDC:677.494.7 doi:10.5937/ZasMat1703363R

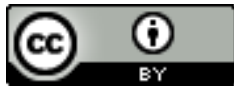

Zastita Materijala 58 (3) $363-368$ (2017)

\title{
The influence of molecular weights on the calcium salts absorption of polyacrylic based materials
}

\begin{abstract}
Most of the industries use water as medium for heating, cooling and also washing of the equipment and facing problems caused by hard water which consist of carbonate and sulfate salts which remain on the walls of reactors and pipes. For this reason, different water softeners are used, with ability to absorb metallic ions and prevent agglomeration of salts on surfaces. Polymeric materials, especially polycarboxylates, can be used to prevent this problem. In this work the influence of molecular weight and molecular composition of poly(acrylic acid-co-maleic acid) carboxylate copolymer on the calcium salts absorption was investigated. Copolymers were prepared by radical polymerization in water-borne system using potassium persulfate as initiator and iron ions $\left(\mathrm{Fe}^{2+}\right)$ as chain length regulator. Molecular structures of obtained polymers were analyzed by FTIR method, and confirmed copolymer structure of resulted polymers. Average molecular weights and degree of polydispersity were determined by GPC. From the results of molecular weights determination it can be concluded that increasing of $\mathrm{Fe}^{2+}$ content leads to decreasing of the molecular weights of copolymers. Presence of ordered structures was confirmed using X-ray diffraction method (XRD). Dispersing capacity results of obtained copolymers have showed that with decreasing of molecular weights of copolymers calcium carbonate dispersing capacity $(C C D C)$ decreased.
\end{abstract}

Keywords: poly(acrylic acid-co-maleic acid), metal ions absorption, polycarboxylates.

\section{INTRODUCTION}

As polar liquid, water is able to dissolve many organic and inorganic components in smaller or larger degree and depending on source and environment of the water flow, water can be divided into few categories according to salt content [1] The best for human consumption are soft and low mineral waters, but there are only few of a kind in the world. Usually water has high salt content which can cause many problems in water supply systems and industries where water is used for heating and washing [2]. Hard water can cause chemical and bio-corrosion of materials and also influences heat exchange processes [1].

Heavy metals and their salts are usually present in water from industrial wastewater and cause big problem in ecosystem, and some of them are very rare and precious and can be reused for some applications [3, 4]. There are many techniques for

\footnotetext{
${ }^{*}$ Corresponding author: Ivan Ristić

E-mail: ivan.ristic@uns.ac.rs

Paper received: 29. 06. 2017.

Paper accepted: 12. 07. 2017.

Paper is available on the website:

www.idk.org.rs/journal
}

heavy metal removal from water, many of them are easy to use, but additional processing of metallic waste is needed, which increases the price of whole process [5]. Some of these are precipitation, solvent extraction, different kinds of filtration, ionexchange, flotation and coagulation. Adsorption is nowaday very popular for use for metal ions removal, but the greatest limitation is low adsorption capacity of adsorbents and weak interactions with metallic ions [6]. Polymer and polymer based absorbents can also be successfully used for removal of pollution from water [7].

Acrylamide and acrylic acid based polymers have a great potential of application in flocculation process [8]. Acrylic acid-based homopolymers and copolymers can be employed as flocculating and dispersing agents, depending on molecular weight and carboxyl content [9]. Polymers with low molecular weight and high carboxyl content act as suspending agents and can be used to keep the calcium away from precipitating. On the other hand, if the molecular weight is high (above $300000 \mathrm{~g} \mathrm{~mol}^{-1}$ ) and the carboxyl content is low, the polymers can be used as flocculants. Polymers with high carboxyl content can be obtained by 
copolymerization of acrylic and maleic acid. The family of linear copolymers poly(acrylic acid-comaleic acid) (poly(AA-MA)) covers different products with a molecular weight within the range of 12,000 to $100,000 \mathrm{~g} \mathrm{~mol}^{-1}$. The AA/MA copolymer mostly used in detergents has MW of about $70000 \mathrm{~g} \mathrm{~mol}^{-1}$ [10].

Reaction mechanism for preparing acrylic acid based copolymers is radical polymerization, using different oxo- and amino-based initiators. It is exothermic reaction that is carried on in temperature range of $60-70{ }^{\circ} \mathrm{C}$ [11]. The present work proposes synthesis of acrylic acid and maleic anhydride based copolymers by radical polymerization in water solution. The influence of molecular weights of obtained copolymers on the metal absorption is discussed.

\section{EXPERIMENTAL}

Acrylic acid (AA) (98\%), maleic anhydride (MA), potassium persulfate (KPS) and iron(II)sulfate $7 \mathrm{H}_{2} \mathrm{O}\left(\mathrm{Fe}^{2+}\right)$ were purchased from Fisher Scientific. Synthesis was carried on in distilled water as reaction medium. Poly(acrylic acid-co-maleic acid) (poly(AA-co-MA) (Figure 1) copolymers with differrent molecular weights were prepared by free-radical polymerization in water medium. Appropriate amounts of $\mathrm{AA}$ and $\mathrm{MA}$ (up to $40 \mathrm{wt} \%$ monomer content) in molar ratio $80 / 20$ and $70 / 30$, respectively, were added to distilled water and mixed until homogenized. Initiator KPS was added in the amount of $1 \%$, while concentrations of chain length regulator $\mathrm{Fe}^{2+}$ ions were 1,3 and $5 \mathrm{wt} \%$ to the monomers content. Mixtures were stirred for $4 \mathrm{~h}$ at temperature of $60^{\circ} \mathrm{C}$.

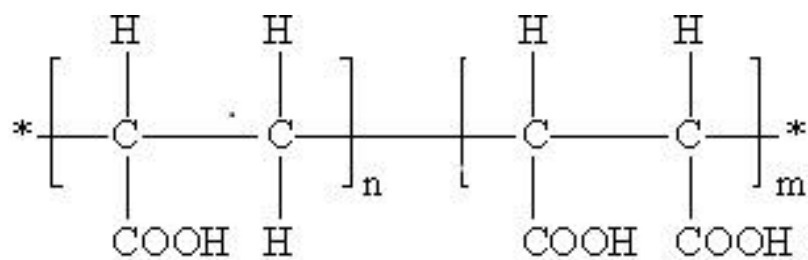

Figure 1. Chemical structure of poly (acrylic acid-comaleic acid) copolymers

Slika 1. Hemijska struktura kopolimera poli(akrilna kiselina-ko-maleinska kiselina)

Molecular structure characterization of synthesized poly(AA-co-MA) copolymers was performed by Fourier transformed infrared spectroscopy (FTIR spectrophotometer Bomem Hartmann \&amp; Braun MB-series). The absorption spectra were recorded in transmission in the range of $4000-400$ $\mathrm{cm}^{-1}$, using $\mathrm{KBr}$ pellets for the sample preparation. Approximately 16 scans with spectral resolution 4 $\mathrm{cm}^{-1}$ were added to achieve a good signal-to-noise ratio.
Gel permeation chromatography (GPC) was used for determination of average molecular weights and the degree of polydispersity $(\mathrm{Q})$, using HPLC - GPC Agilent 1100 Series with RID detector 1200 Series. The column used for the molecular weights determination was in the range of $10^{2}-10^{6}$ $\mathrm{g} / \mathrm{mol}$ was ZORBAX - BIMODAL - S, $250 \times 6,2$ $\mathrm{mm}, 5 \mu \mathrm{m}$. Solutions of sodium salts of poly(styrenesulfonate) in water, with narrow molecular weight distribution were used as calibration standards.

Calorimetric measurements were performed in a TA Instruments Q20 DSC apparatus. Nitrogen gas was let through the DSC cell with a flow rate of $50 \mathrm{~mL} / \mathrm{min}$. The temperature of the equipment was calibrated with indium. The melting heat of indium was used for calibrating the heat flow. Samples mass was ca $6 \mathrm{mg}$. First, the samples were heated with a heating rate of $10^{\circ} \mathrm{C} \mathrm{min}{ }^{-1}$ from $20^{\circ} \mathrm{C}$ to 180 ${ }^{\circ} \mathrm{C}$ (to erase thermal history), then cooled to $20^{\circ} \mathrm{C}$, at a rate of $20^{\circ} \mathrm{C} \mathrm{min}{ }^{-1}$, at $20^{\circ} \mathrm{C}$ sample was kept for 5 minutes and then again heated to $200{ }^{\circ} \mathrm{C}$, at a rate of $10{ }^{\circ} \mathrm{C} \mathrm{min}^{-1}$. Second heating scans were used in determination of thermal parameters of copolymers. Glass transition temperatures $\left(T_{g}\right)$ were determined by means of the inflexion points on the calorigrams. Melting temperatures $\left(T_{m}\right)$ were determined by positions of melting endotherm peaks. Specific melting enthalpies $\left(\Delta \mathrm{H}_{\mathrm{m}}\right)$ were calculated from area below endotherm peaks.

$X$-ray diffraction measurements were performed using Diffractometer PW 1729 CuKa, XRD Philips. Starting angle $2 \Theta$ was $5^{\circ}$, ending $40^{\circ}$ and step $0,05^{\circ}$. Exposition time hold at every point was $1 \mathrm{~s}$.

The ability of the acrylate based copolymer to inhibit incrustation is the result of its capacity to disperse sparingly water-soluble solids. One of the methods for determination of dispersing capacity is titration of the dispersing agent solution with calcium acetate $(\mathrm{CaAc})$ in the presence of an excess of carbonate ions until opalescence occurs. For calcium carbonate dispersing capacity test (CCDC) $1.0 \mathrm{~g}$ of acrylate-copolymer was dissolved in $100 \mathrm{ml}$ of distilled water and neutralized. $\mathrm{pH}$ value of the solution was adjusted to 11 , by adding $10 \mathrm{ml}$ of $10 \%$ sodium carbonate solution. Solution was then titrated with $0,25 \mathrm{M}$ calcium acetate solution, maintaining the $\mathrm{pH}$ and temperature at a constant level.

\section{RESULTS AND DISCUSSION}

Figure 2 shows FTIR spectrum of PAAcoMA$70 / 30-1 \mathrm{Fe}^{2+}$ copolymer. The strong and broad absorption band cantered at $3427 \mathrm{~cm}^{-1}$ is attributed to $\mathrm{O}-\mathrm{H}$ stretching. Position of this band is redshifted significantly relative to the peak of stretching of free hydroxy group in diluted solutions of 
carboxy acids observed at ca $3500 \mathrm{~cm}^{-1}$. This gives evidence about participation of hydroxy groups in the copolymer chains in strong secondary (H-bonding) interactions with other carbonyl and hydroxy groups present in the same or neighbour copolymer chains.
The two strong overlapping peaks at $1650 \mathrm{~cm}^{-1}$ and $1553 \mathrm{~cm}^{-1}$ can be probably attributed to stretching vibration $\mathrm{C}=\mathrm{O}$ in neutral and ionized carboxy groups, respectively.

There was no absorption peaks at $1820 \mathrm{~cm}^{-1} \sim$ $1840 \mathrm{~cm}^{-1}$ of the anhydride groups, or $665 \mathrm{~cm}^{-1}$ to $995 \mathrm{~cm}^{-1}$ of the $\mathrm{C}=\mathrm{C}$ groups in the polymer [12]

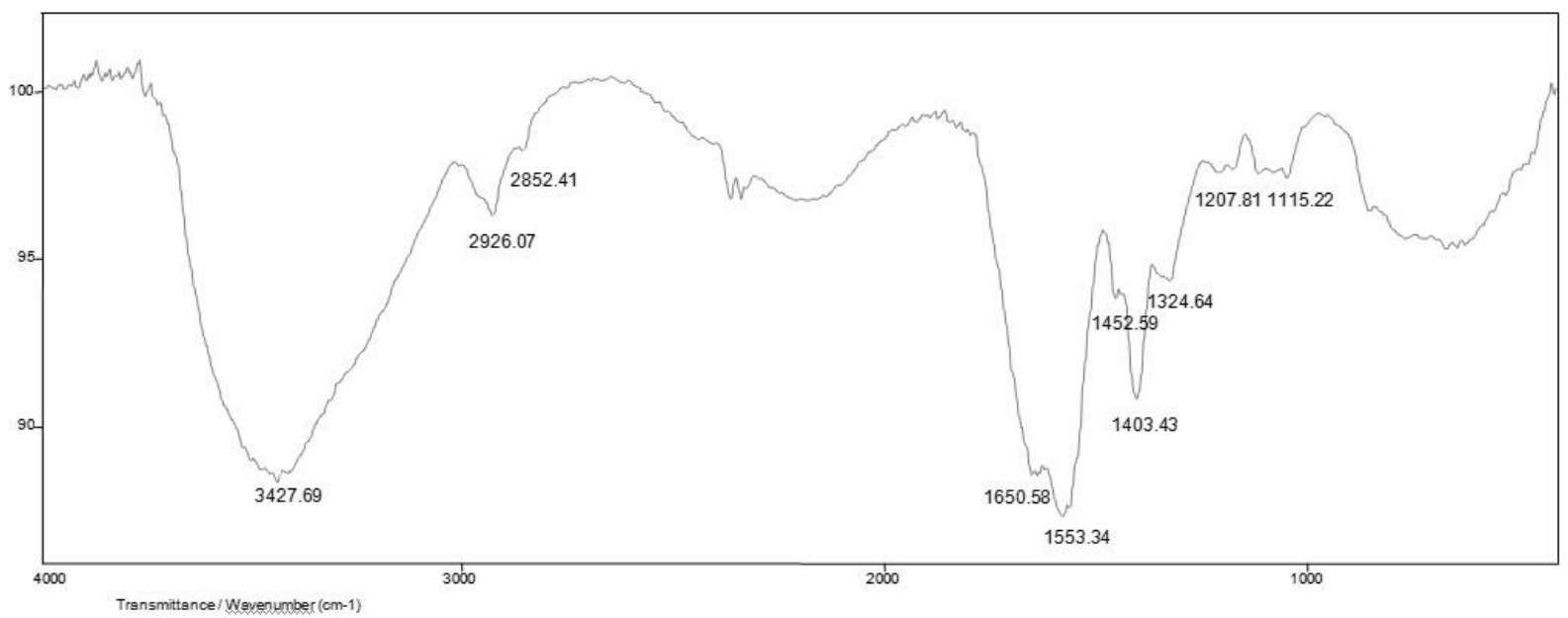

Figure 2. FT-IR spectra of copolymer PAAcoMA-70/30-1Fe ${ }^{2+}$

Slika 2. FT-IR spektar kopolimera PAAcoMA-70/30-1Fe ${ }^{2+}$

Results of average molecular weights measurements, polydispersity, amount of unreacted monomer and calcium carbonate dispersing capacity (CCDC) are shown in the Table 1 . As it can be seen, concentration of $\mathrm{Fe}^{2+}$ and molecular weight of copolymer are inversely related, so with increasing of $\mathrm{Fe}^{2+}$ content molecular weight decreases. This also had an influence on degree of polydispersity, which increased with decreasing of molecular weights, but still remains in the range where controlled polymerization is possible to perform. The amount of unreacted monomer is very low for all samples, around and below 2\% which indicates on successful polymerization, and slightly decreased with increasing of $\mathrm{Fe}^{2+}$ content in reaction medium.

CCDC values for synthesized copolymers were around $300 \mathrm{mg} \mathrm{CaO} / \mathrm{g}$, except for sample with highest amount of $\mathrm{Fe}^{+2}$, and CCDC decreased with decreasing of molecular weights of copolymers.

Table 1. Average molecular weights of samples, degree of polydispersity, amount of unreacted monomer and CCDC values

Tabela 1. Srednje molekulske mase uzoraka, stepen polidisperznosti, količina neproreagovalog monomera i vrednosti CCDC

\begin{tabular}{|c|c|c|c|c|}
\hline Sample & $\bar{M}_{n}, \mathrm{~g} / \mathrm{mol}$ & $\mathrm{Q}$ & $\begin{array}{c}\text { Unreacted } \\
\text { monomer, } \%\end{array}$ & $\begin{array}{c}\text { CCDC, mg } \\
\mathrm{CaO} / \mathrm{g}\end{array}$ \\
\hline PAAcoMA-70/30-1Fe ${ }^{2+}$ & $8,51 \cdot 10^{4}$ & 1,78 & 1,96 & 310 \\
\hline PAAcoMA-70/30-3Fe ${ }^{2+}$ & $7,04 \cdot 10^{4}$ & 2,25 & 0,51 & 330 \\
\hline PAAcoMA-70/30-5Fe ${ }^{2+}$ & $6,12 \cdot 10^{4}$ & 2,43 & 0,68 & 305 \\
\hline PAAcoMA-80/20-1Fe ${ }^{2+}$ & $5,01 \cdot 10^{4}$ & 2,19 & 1,85 & 282 \\
\hline PAAcoMA-80/20-3Fe & $4,72 \cdot 10^{4}$ & 2,35 & 1,95 & 257 \\
\hline PAAcoMA-80/20-5Fe & $4,54 \cdot 10^{4+}$ & 2,24 & 1,54 & 236 \\
\hline
\end{tabular}

${ }^{*}$ PAAcoMA-70/30-1Fe $\mathrm{Fe}^{2+}$ - represents the sample of poly (acrylic acid-co-maleic acid) with $70 \mathrm{wt} \%$ of acrylic acid in copolymer and $1 \mathrm{wt} \%$ of $\mathrm{Fe}^{2+}$ in synthesis

The thermal properties of the obtained samples were analyzed by DSC and the results are illustrated in Figure 3 and summarized in Table 2. From the obtained DSC results it can be concluded that the increase of the maleic acid content is accompanied by increase in the values of $T_{g}, T_{m}$ and $\Delta \mathrm{H}_{\mathrm{m}}$. As shown above, presence of secondary interactions in the investigated copolymers is approved by FTIR. Therefore, the observed increase of $\mathrm{T}_{\mathrm{g}}, \mathrm{T}_{\mathrm{m}}$ and $\Delta \mathrm{H}_{\mathrm{m}}$ values can be 
explained in the following way. Molecule of maleic acid has two $\mathrm{COOH}$ groups, unlike molecule of acrylic acid which has one $\mathrm{COOH}$ group, only. Consequently, presence of maleic acid in copolymer chains increases number of groups able of secondary interactions (such as hydrogen bonding) on polymer chain which results in decreased mobility of polymer segments and, consequently, the increased Tg value, (see Table 2 and Figure 3). This also improves orientation of polymer segments, and increases ordering of polymer chains, which is reflected in the increase in the value of the melting enthalpy, as the content of maleic acid increasing. The increase of concentration of $\mathrm{Fe}^{2+}$ ion, such as polymer chains length regulator, shows more influence on the thermal properties of the samples with a greater content of maleic anhydride. This effect can be explained by a strong influence of $\mathrm{Fe}^{2+}$ ion on the polymer molar mass. Data presented in Table 2 show that the addition of 5 wt $\% \mathrm{Fe}^{2+}$ ion reduces molar mass as much as $25000 \mathrm{~g} \mathrm{~mol}^{-1}$ as compared to samples with $1 \mathrm{wt} \%$ of $\mathrm{Fe}^{2+}$ ions, for samples with higher content of maleic acid. Because of this, the decreasing of $\mathrm{Tg}$, $\mathrm{Tm}$ and $\Delta \mathrm{Hm}$ values were more noticeable for samples with $30 \mathrm{wt} \%$ of maleic acid compared to the samples of copolymers with a 20 wt\% of maleic acid, Table 2 . Increasing the $\mathrm{Fe}^{2+}$ ion content not affect the $\mathrm{Tm}$ value, as it was expected, because, the same arranged structure melt at similar temperature, but resulted in lower $\Delta \mathrm{Hm}$ values, probably due to reduction of the molecular weight and crystalinity by the addition of iron.

Table 2. Thermal properties of obtained carboxylate copolymers: glass transition temperature (Tg), melting temperature (Tm) and specific melting enthalpy $(\Delta \mathrm{Hm})$

Tabela 2. Toplotna svojstva sintetisanih karboksilatnih kopolimera: temperatura prelaska u staklasto stanje (Tg), temperatura topljenja (Tm) i entalpija topljenja $(\Delta \mathrm{Hm})$

\begin{tabular}{|l|c|c|c|}
\hline \multicolumn{1}{|c|}{ Sample } & $\mathrm{Tg},{ }^{\circ} \mathrm{C}$ & $\mathrm{Tm},{ }^{\circ} \mathrm{C}$ & $\Delta \mathrm{H}^{2} \mathrm{~J} \mathrm{~g}^{-1}$ \\
\hline PAAcoMA-70/30-1Fe ${ }^{2+}{ }^{-1}$ & 68 & 177 & 5,67 \\
\hline PAAcoMA-70/30-3Fe ${ }^{2+}$ & 64 & 173 & 4,82 \\
\hline PAAcoMA-70/30-5Fe ${ }^{2+}$ & 59 & 172 & 4,01 \\
\hline PAAcoMA-80/20-1Fe ${ }^{2+}$ & 57 & 171 & 4,89 \\
\hline PAAcoMA-80/20-3Fe ${ }^{2+}$ & 56 & 171 & 4,26 \\
\hline PAAcoMA-80/20-5Fe & 53 & 170 & 3,98 \\
\hline
\end{tabular}

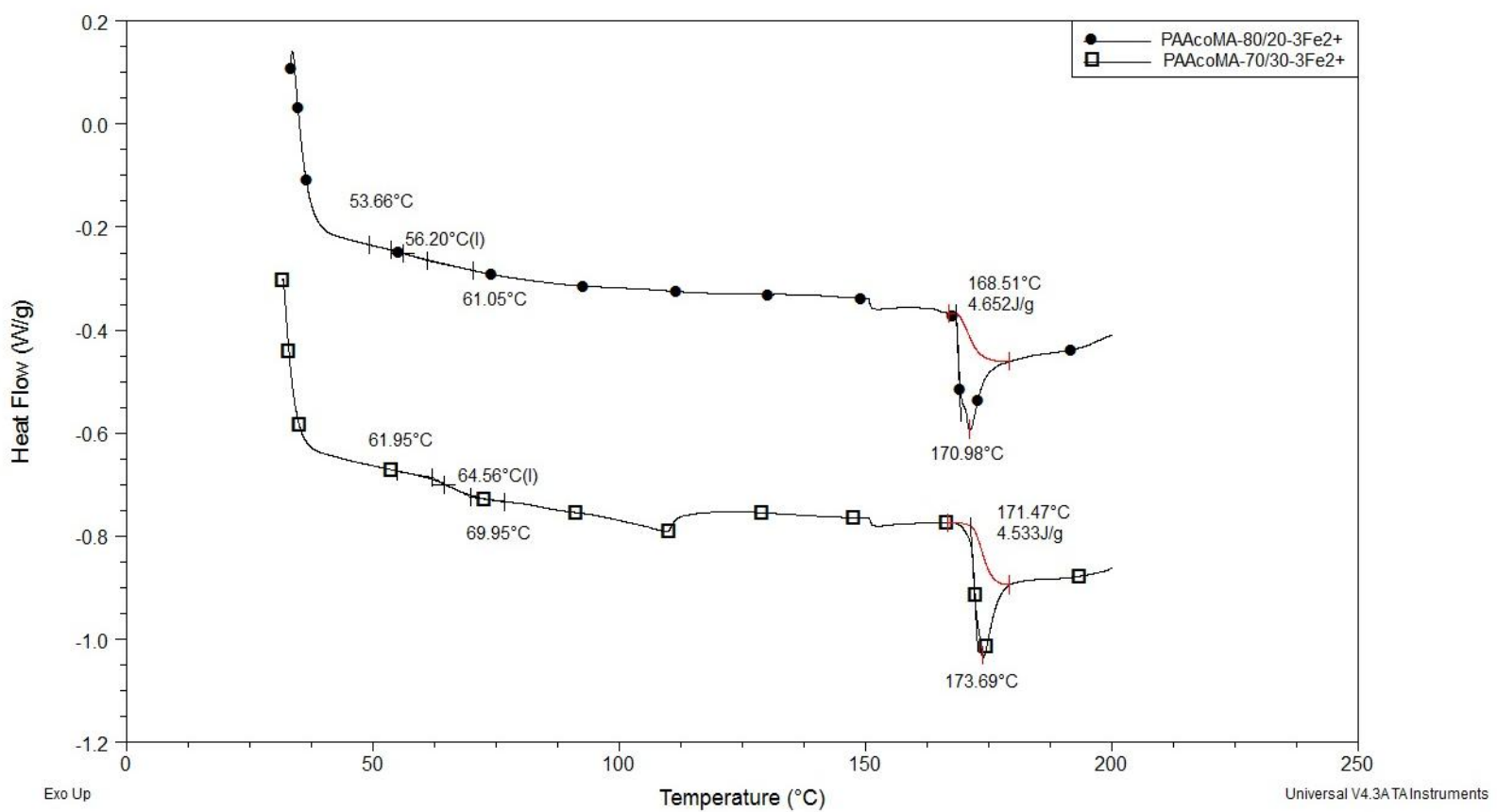

Figure 3. DSC curves of carboxylate copolymers (•) PAAcoMA-80/20-3Fe2+ and ( $\square$ ) PAAcoMA-70/30$3 \mathrm{Fe}^{2+}$ obtained in second heating at $10^{\circ} \mathrm{C} / \mathrm{min}$

Slika 3. DSC krive karboksilatnih kopolimera (•) PAAcoMA-80/20-3Fe ${ }^{2+} i$ () PAAcoMA-70/30-3Fe $e^{2+}$, snimljenih prilikom drugog zagrevanja, brzinom $10^{\circ} \mathrm{C} / \mathrm{min}$ 
Crystalline structure of synthesized copolymers observed by DSC is confirmed by XRD analysis (see Figure 4). Two diffraction peaks at 10,8 and $17,2^{\circ}$ in copolymer with $70 \% \mathrm{PA}$ and $3 \% \mathrm{Fe}^{2+}$ (Figure $4 . \mathrm{a}$ ) and one peak at $18,6^{\circ}$ in copolymer with $80 \%$ of PA and $3 \%$ of $\mathrm{Fe}^{2+}$ (Figure $4 . \mathrm{b}$ ) were detected. More ordered structure is found in copolymers with higher amount of maleic acid, due to higher concentration of carboxylic functional groups participating in ionic and hydrogen bonding.
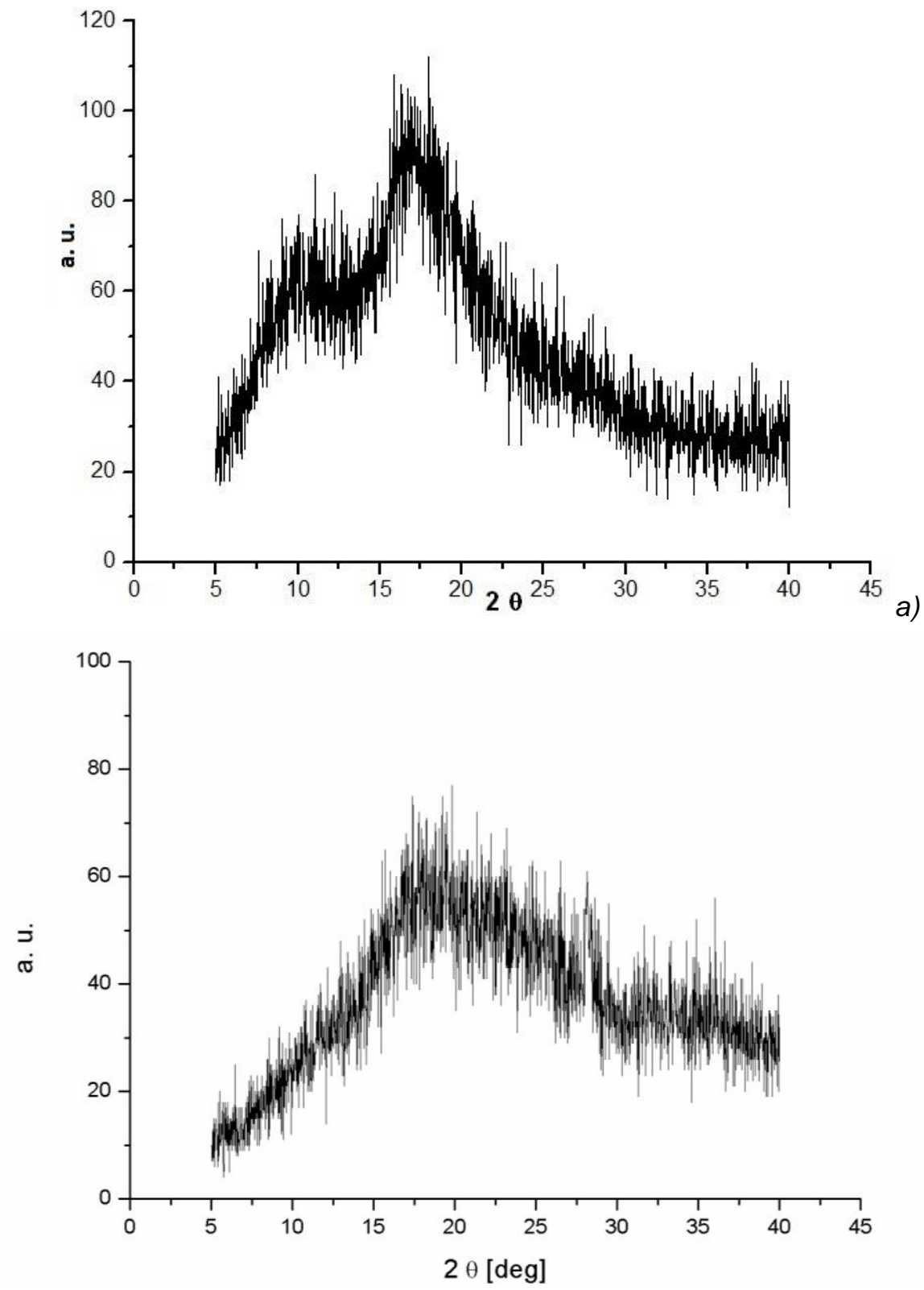

b)

Figure 4. XRD graph of a) PAAcoMA-70/30-3Fe2+ and b) PAAcoMA-80/20-3Fe2+copolymers Slika 4. XRD difraktogram a) PAAcoMA-70/30-3Fe ${ }^{2+}$ i b) PAAcoMA-80/20-3Fe ${ }^{2+}$ kopolimera

\section{CONCLUSION}

By using $\mathrm{Fe}^{2+}$ ions as chain length regulator it is possible to control molecular weights of synthesized carboxylated polymer and obtain copolymers with desired properties. Increasing amount of $\mathrm{Fe}^{2+}$ used in the synthesis leads to formation of copolymers with shorter chains (lower molar mass) and lower calcium carbonate capacity. DSC results show that higher maleic acid content in copolymers increases in the values of glass transition tempe- rature, melting temperature and specific melting enthalpy. In agreement with FTIR results, this observation is attributed to higher number of carboxy groups able of strong secondary (ionic and $\mathrm{H}$ bonding) interactions brought to copolymer chains by maleic acid molecules during synthesis. Increased number of secondary interactions between copolymer chains is also reflected in higher ordering of polymer segments observed by XRD analysis. 


\section{Acknowledgements}

We would like to thank Ministry of Education, Science and Technological Development Republic of Serbia for funding projects III45022 and OI171015.

\section{REFERENCES}

[1] B.Valdez, M.Schorr, R.Zlatev, M.Carrillo, M. Stoytcheva, L.Alvarez, A.Eliezer, N.Rosas (2012) Corrosion Control in Industry, knjiga Environmental and Industrial Corrosion - Practical and Theoretical Aspects, InTECH, Rijeka, Croatia, p. 19-53

[2] B.Valdez, N.Rosas, J.Sampedro, M.Quintero, J.Vivero (1999) Influence of elemental sulphur on corrosion of carbon steel in geothermal environments, Corrosion Reviews, 17(3- 4), 167-180

[3] M.Jha, J.Lee, M.Kim, J.Jeong, B.Kim, V.Kumar (2013) Hydrometallurgical recovery/recycling of platinum by the leaching of spent catalysts: A review, Hydrometallurgy, 133, 23-32

[4] S.Syed (2012) Recovery of gold from secondary sources-A review, Hydrometallurgy, 115-116, 3051

[5] M.Barakat (2011) New trends in removing heavy metals from industrial wastewater, Arabian Journal of Chemistry, 4(4), 361-377

[6] F.Fu, Q.Wang (2011) Removal of heavy metal ions from wastewaters, Journal of Environmental Management, 92(3), 407-4018
[7] B.Pan, B.Pan, M.Zhang, L.Lv, Q.Zhang, S.Zheng (2009) Development of polymeric and polymerbased hybrid adsorbents for pollutants removal from waters, Chemical Engineering Journal, 151, 19-29

[8] G.Graciun, D.Ighigeanua, E.Manailaa, M.Maria Stelescub (2015) Synthesis and Characterization of Poly(Acrylamide-Co-Acrylic Acid) Flocculant Obtained by Electron Beam Irradiation, Materials Research, 18(5), 984-993

[9] W.Linke, R.Booth (1960) Physical chemical aspects of flocculation by polymers, Transactions of the Metallurgical Society of AIME, 217, 364-371

[10] Z.Amjad, W.Zuhl, S.Huang, (2012) Deposit Control Polymers: Types, Characterization, and Applications, knjiga The Science and Technology of Industrial Water Treatment, CRC Press, Boca Raton, FL, p. 447-463

[11] I. Ristić, A. Miletić, S.Cakić, O.Govedarica, M. Janković, S.Sinandinović-Fišer, J.Budinski-Simendić, (2016) 13th International Conference on Fundamental and Applied Aspects of Physical Chemistry, Proceedings, p. 685-688

[12] S.Zhou, B.Jiang, H.Pang, B.Wang, B.Liao (2013) RAFT polymerization of poly (acrylic acid-co-maleic anhydride) as dispersant for raw ceramic suspension, Journal of Ceramic Processing Research, 14(3), 415-418

\title{
IZVOD
}

\section{UTICAJ MOLEKULSKE MASE POLIAKRILATNIH MATERIJALA NA SVOJSTVA ABSORPCIJE KALCIJUMOVIH SOLI}

\begin{abstract}
Većina industrijskih postrojenja koristi vodu kao medijum za grejanje, hlađenje i pranje opreme suočava se sa problemima izazvanim tvrdom vodom koja sadrži karbonatne $i$ sulfatne soli koje zaostaju na zidovima reaktora i cevi. Iz ovog razloga, koriste se različiti omekšivači vode, sa sposobnošću da apsorbuju jone metala i onemoguće aglomeraciju soli na površinama. Polimerni materijali, posebno polikarboksilati, mogu se koristiti za sprečavanje ovih problema. U ovom radu je ispitivan uticaj molekulske mase i molekulskog sastava poli(akrilna kiselina - ko - maleinska kiselina) karboksilatnih kopolimera na apsorpciju kalcijumovih soli. Kopolimeri su sintetisani postupkom radikalne polimerizacije u vodenom rastvoru korišćenjem kalijum-persulfata kao inicijatora i jona gvožđa $\left(\mathrm{Fe}^{2+}\right)$ kao regulatora dužine lanaca. Molekulske strukture dobijenih polimera analizirane su FT-IR metodom i potvrđeno je da je dobijeni polimer kopolimerne strukture. Srednja molekulska masa i stepen polidisperznosti uzoraka određeni su GPC metodom. Rezultati merenja molekulskih masa pokazuju da sa povećanjem udela $\mathrm{Fe}^{2+}$ jona opada molekulska masa kopolimera. Prisustvo uređene strukture potvrđeno je korišćenjem difrakcije $X$ zraka. Rezultati ispitivanja kapaciteta dispergovanja dobijenih kopolimera pokazali su da se sa smanjenjem molekulske mase smanjuje kapacitet dispergovanja soli kalcijum-karbonata.
\end{abstract}

Ključne reči: poli(akrilna kiselina - ko - maleinska kiselina), apsorpcija metalnih jona, polikarboksilati.

Naučni rad

Rad primljen: 29. 06. 2017.

Rad prihvaćen: 12. 07. 2017.

Rad je dostupan na sajtu: www.idk.org.rs/casopis

(C) 2017 Authors. Published by Inženjersko društvo za koroziju. This article is an open access article distributed under the terms and conditions of the Creative Commons Attribution 4.0 International license (https://creativecommons.org/licenses/by/4.0/) 